\title{
THE EFFECT OF MICROSTRUCTURE BANDING ON THE MECHANICAL AND TECHNOLOGICAL PROPERTIES OF WIRE ROD OF COLD UPSETTING STEEL
}

\author{
Konrad LABER \\ Czestochowa University of Technology, Faculty of Production Engineering and Materials Technology, \\ Institute for Plastic Working and Safety Engineering, Czestochowa, Poland, EU \\ laber.konrad@wip.pcz.pl
}

https://doi.org/10.37904/metal.2019.863

\begin{abstract}
The paper presents the results of investigation into the effect of structure banding on the mechanical and technological properties of finished wire rod. It describes also the causes of the formation of banding and the possibility of reducing it by changing the thermoplastic working parameters. Tests were carried out for a lowcarbon ferritic-pearlitic steel intended for further cold plastic working. The test results have shown that the occurring banding adversely affects the mechanical and technological properties of the steel grade under study. Within the study, the rolling end temperature and cooling rate that reduce the banding and improve the finished product properties have been determined.
\end{abstract}

Keywords: Microstructure banding, mechanical properties, technological properties, cold upsetting steel, wire rod thermoplastic working

\section{INTRODUCTION}

The condition for obtaining a finished product with the highest possible microstructural homogeneity is to employ thermoplastic working parameters properly selected for the steel grade and finished product type in question [1]. This is particularly important for processes with a small plastic working degree and steels containing elements exhibiting a tendency to segregation, such as manganese or phosphorus $[1 \div 3]$. As a result of the segregation of $\mathrm{Mn}$, which significantly changes the temperature of transition of austenite into ferrite and is shows a small diffusion coefficient, a banded microstructure may form in products, which would contribute to the formation of material defects during subsequent plastic working of the steel $[1,4]$. Study [5] shows that the banded microstructure adversely affects the impact resistance of steel and, to a lesser extent, also its other properties. It has been found that banding does not significantly affect the yield point or tensile strength of steel and does not cause the anisotropy of these properties. Work [6] has found, on the other hand, that steels with a banded structure may exhibit a great anisotropy of plastic properties. Reference [4] has demonstrated that the lower the cooling rate and the finer the grains of austenite recrystallized immediately prior to the start of the transition, the greater the tendency to the formation of a banded microstructure. It has also been found that the formation of a banded microstructure is favoured by the structure of austenite not recrystallized before the start of the transition. Tests carried out within study [4] established the cooling rate of recrystallized austenite at $3{ }^{\circ} \mathrm{C} / \mathrm{s}$, after exceeding of which no microstructural banding occurred. This cooling rate did not protect against banding in the case of the structure of elongated and deformed austenite grains [1]. The effect of $\mathrm{Mn}$ segregation in the stock and a low cooling rate (approx. $0.1{ }^{\circ} \mathrm{C} / \mathrm{s}$ ) during austenite transformation on microstructure banding is also confirmed by the results reported in publication [7]. Study [8] has found that micro-segregation of elements, such as $\mathrm{Mn}, \mathrm{Cr}$ and Si during the solidification of steel is a prerequisite for the formation of banding of the ferrite-pearlite type, but the decisive factor is the kinetics of the phase transformation of austenite during cooling. References $[1,9]$ have found that the primary cause of the formation of microstructural banding is chemical inhomogeneity in micro-regions, resulting from the dendritic mechanism of continuous casting solidification. By properly selecting the parameters of the con-cast rolling process, the banding can be minimized, but the primary cause of its formation cannot be eliminated. The microstructural 
banding may "come back" in subsequent heat treatment or thermoplastic working operations. Investigation into the effect of the conditions of thermoplastic working on the microstructure and properties of wire rod of low-carbon steel was also conducted by the authors of study [10].

A review the literature concerning primarily the influence of microstructural banding on the mechanical properties of finished product has shown that the views of different authors on this matter are divided. Therefore, it is justifiable to undertake further studies to explain the effect of microstructural banding on the mechanical and technological properties of low-carbon steel wire rod intended for subsequent cold plastic working. It is also advisable to determine the specific cooling rate for low-carbon wire rod intended for cold upsetting after the rolling process.

\section{THE AIM, SCOPE AND METHODOLOGY OF INVESTIGATION}

The main aim of the study was to determine the effect of microstructural banding on the mechanical and technological properties of $5.5 \mathrm{~mm}$-diameter 20MnB4 steel wire rod intended for cold plastic working. The paper describes also the causes of the formation of banding in ferritic-pearlitic structure steel and the possibility of its reduction by changing the thermoplastic working parameters. Based on the analysis of the obtained results, the rolling end temperature and cooling rate have been determined, which reduce the banding and improve the finished product properties. The end rolling temperature for rolling 20MnB4 steel band in the RSM (Reducing Sizing Mill) block of the Wire Rod Rolling Mill, and the cooling rate in the STELMOR® line (Table 1) have been determined based on the analysis of commercial low-carbon upsetting steel wire rod rolling technologies and the author's previous studies. Based on investigation results published, inter alia, in references [6,11], it has been found that the most advantageous range of cooling rate for steel $20 \mathrm{MnB} 4$ after the rolling process is from 5 to $15^{\circ} \mathrm{C} / \mathrm{s}$. Increasing the cooling rate results in the formation of bainitic, bainiticmartensitic and martensitic structures in the wire rod, which impairs the ability of steel to be cold deformed or, in extreme cases, makes the deformation impossible. In turn, using lower cooling rates may cause an inhomogeneity of the size and shape of ferrite grains and favours the formation of a banded steel microstructure, which is characterized by the occurrence of ferrite and pearlite in the form of alternately positioned bands.

Table 1 The parameters of thermoplastic working during rolling $5.5 \mathrm{~mm}$-diameter 20MnB4 steel wire rod

\begin{tabular}{|c|c|c|c|c|}
\hline \multirow{2}{*}{ Variant } & $\begin{array}{c}\text { Temperature } \\
\text { before the RSM } \\
\text { block }\left({ }^{\circ} \mathrm{C}\right)\end{array}$ & Stage 1 & Stage 2 & \multirow{2}{*}{$\begin{array}{c}\text { Settings of heat-insulating } \\
\text { covers and fans }\end{array}$} \\
\cline { 3 - 5 } & 850 & up to $470^{\circ} \mathrm{C}-5^{\circ} \mathrm{C} / \mathrm{s}$ & from $470{ }^{\circ} \mathrm{C}$ to $200^{\circ} \mathrm{C}-1^{\circ} \mathrm{C} / \mathrm{s}$ & covers open, fans shut down \\
\hline 1 & 850 & up to $485^{\circ} \mathrm{C}-10^{\circ} \mathrm{C} / \mathrm{s}$ & from $485{ }^{\circ} \mathrm{C}$ to $200{ }^{\circ} \mathrm{C}-1{ }^{\circ} \mathrm{C} / \mathrm{s}$ & $\begin{array}{l}\text { covers open, fan rotational speed } \\
75 \% \text { of the maximum value }\end{array}$ \\
\hline 2 & 800 & up to $545^{\circ} \mathrm{C}-0.5^{\circ} \mathrm{C} / \mathrm{s}$ & from $545^{\circ} \mathrm{C}$ to $200^{\circ} \mathrm{C}-1^{\circ} \mathrm{C} / \mathrm{s}$ & covers closed, fans shut down \\
\hline 3 & & &
\end{tabular}

Mechanical tests were carried out in the static tensile test in accordance with standard PN-EN ISO 68921:2016-09. Wire rod torsion tests were performed following the guidelines given in study [12]. For the tests, specimens with a length of 50D ( $\mathrm{D}$ - final wire rod diameter $(\mathrm{mm})$ ) were used, which were loaded with an axial force being equal to $2 \%$ of the maximum breaking force. Bending tests were conducted on rolls, each of a diameter of $30 \mathrm{~mm}$. Another quantity that is used in determining the plastic deformability of steel is the total redundant strain angle $y$ and the total true longitudinal strain $\varepsilon$, as determined from the wire rod torsion test. Studies $[12,13]$ show, that relationship (1) occurs between the torsional angle $\varphi$ and the redundant strain angle $\mathrm{Y}$. If the twisted wire rod length is $50 \mathrm{D}$ and the twist angle is $2 \pi \mathrm{N}$ ( $\mathrm{D}$ - final wire rod diameter $(\mathrm{mm}), \mathrm{N}$ - number of twists), then the redundant strain angle $y$ on the external surface can be calculated from relationship (2). The true longitudinal strain after twisting by an angle of $y$ can be calculated from formula (3): 
$R=\operatorname{tg} \gamma$

$\operatorname{tg} \gamma=\frac{R \cdot 2 \pi \cdot N}{100 \cdot R}=\frac{\pi \cdot N}{50}$

$\varepsilon=\ln \sqrt{1+\left(\frac{\pi \cdot N}{50}\right)^{2}}$

where: $\mathrm{R}$ - wire rod radius $(\mathrm{mm}), \mathrm{N}$ - number of twists $\mathrm{In}$ each case, 6 samples were taken for testing ( 3 from the central part of the rolled band and 3 from the end part).

\section{ANALYSIS OF THE TEST RESULTS}

Chemical composition of the investigated steel, obtained from melt analysis, is given in Table 2.

Table 2 Chemical composition of the 20MnB4 steel

\begin{tabular}{|c|c|c|c|c|c|c|c|c|c|}
\hline \multicolumn{10}{|c|}{ Constituent contents (\%) } \\
\hline $\mathrm{C}$ & $\mathrm{Mn}$ & $\mathrm{Si}$ & $\mathrm{P}$ & $\mathrm{S}$ & $\mathrm{Cr}$ & $\mathrm{Ni}$ & $\mathrm{Cu}$ & $\mathrm{Al}$ & $\mathrm{Mo}$ \\
\hline 0.21 & 0.97 & 0.10 & 0.014 & 0.009 & 0.26 & 0.07 & 0.17 & 0.024 & 0.014 \\
\hline $\mathrm{N}$ & $\mathrm{Pb}$ & $\mathrm{Al}$ & $\mathrm{As}$ & $\mathrm{Cb}$ & $\mathrm{V}$ & $\mathrm{Ti}$ & $\mathrm{B}$ & $\mathrm{Zn}$ & $\mathrm{Sn}$ \\
\hline 0.0119 & 0.001 & 0.020 & 0.007 & 0.002 & 0.004 & 0.047 & 0.0030 & 0.018 & 0.012 \\
\hline
\end{tabular}

Figure 1 shows sample photographs of the microstructure of $5.5 \mathrm{~mm}$-diameter $20 \mathrm{MnB} 4$ steel wire rod for the examined rolling process variants.
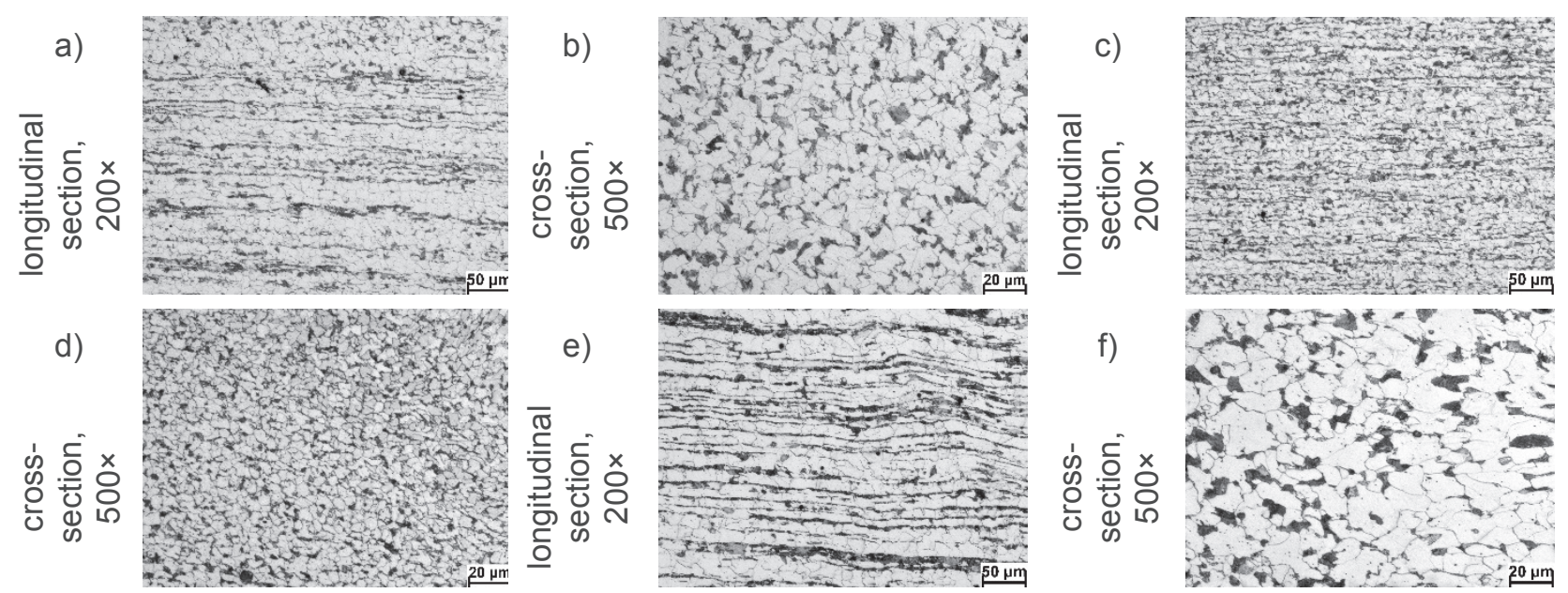

Figure 1 Sample microstructure of $5.5 \mathrm{~mm}$-diameter 20MnB4 steel wire rod after the process of rolling under industrial conditions: a) and b) variant no. 1 ; c) and d) variant no. 2 ; and e) and f) variant no. 3

From the photographs of the microstructure of wire rod obtained in industrial conditions according to variant no. 1 it can be found that the product is characterized by a ferritic-pearlitic structure that is homogeneous in terms of ferrite grain size. However, slight banding was observed in the wire rod microstructure. The average ferrite grain size was approx. $10 \mu \mathrm{m}$. Increasing the rate of cooling after rolling up to $10{ }^{\circ} \mathrm{C} / \mathrm{s}$ (variant no. 2), 
considerably reduced the microstructural banding of the wire rod under investigation. An advantageous refinement of the microstructure of steel $20 \mathrm{MnB} 4$ and even greater its ferrite grain size homogenization was also found. The average ferrite grain size in this case was about $8 \mu \mathrm{m}$. Reducing the band temperature prior to entry to the RSM block down to approx. $800 \mathrm{C}$ and lowering the rate of cooling on the roller conveyor to $0.5{ }^{\circ} \mathrm{C} / \mathrm{s}$ (variant no. 3 ) increased the banding of the rolled steel. As a result of slow cooling, the wire rod had an inhomogeneous, coarse-grained microstructure of an average ferrite grain size of about $16 \mu \mathrm{m}$.

The results of the mechanical testing of the $5.5 \mathrm{~mm}$-diameter 20MnB4 steel wire rod are given in Table 3. Figure 2 shows examples of stress-strain curves for 20MnB4 steel specimens.

Table 3 Mechanical properties of $5.5 \mathrm{~mm}$-diameter 20MnB4 steel wire rod

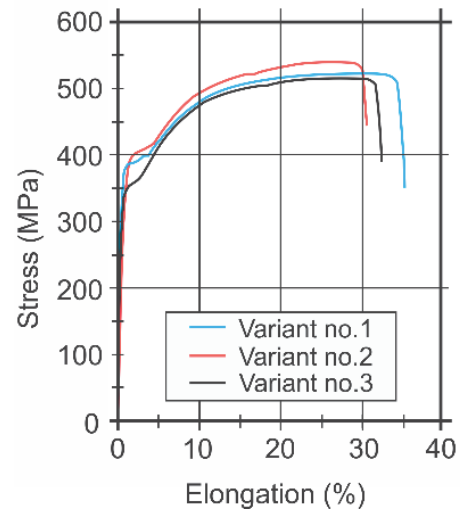

Figure 2 Examples of stress-strain curves

\begin{tabular}{|c|c|c|c|c|c|}
\hline 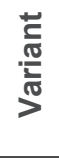 & $\begin{array}{c}\text { Yield } \\
\text { strength } \\
\text { (MPa) }\end{array}$ & $\begin{array}{l}\text { Ultimate tensile } \\
\text { strength } \\
\text { (MPa) }\end{array}$ & $\begin{array}{l}\text { Unit elongation } \\
(\%)\end{array}$ & $\begin{array}{c}\text { Reduction of area } \\
(\%)\end{array}$ & $\begin{array}{c}\text { Margin of plasticity (Yield } \\
\text { Strength/Ultimate tensile } \\
\text { strength) }\end{array}$ \\
\hline 1 & 381 & 522 & 33.3 & 69.5 & 0.73 \\
\hline 2 & 412 & 557 & 29.4 & 69.8 & 0.74 \\
\hline 3 & 324 & 516 & 32.0 & 68.4 & 0.63 \\
\hline
\end{tabular}

When analysing the results of the mechanical testing of the wire rod obtained from rolling in the RSM block at a temperature of $850^{\circ} \mathrm{C}$ and cooling in the STELMOR® line according to variants 1 and 2 it was found that a better complex of mechanical properties was exhibited by wire rod cooled on the roller conveyor at a cooling rate of $10{ }^{\circ} \mathrm{C} / \mathrm{s}$ (variant 2). The yield strength value was greater by approx. $8 \%$ and tensile strength by almost $7 \%$, compared to variant no. 1 . For wire rod produced according to variant no. 2 , a decrease in elongation by approx. $12 \%$ (compared to variant no. 1) occurred; however, it did not adversely affected the deformability of the wire rod tested, as confirmed by the results of upsetting tests. The reduction of area of the wire rod was similar for both variants. After cooling the wire rod down on the roller conveyor at a cooling rate of $10^{\circ} \mathrm{C} / \mathrm{s}$, an increase in the margin of plasticity by about $1.4 \%$ was also found. After rolling and cooling the wire rod according to variant no. 3, a reduction of mechanical properties occurred - in yield strength by over $21 \%$ and in tensile strength by more than $7 \%$. The elongation of the wire rod obtained according to this variant increased by nearly $9 \%$. A decrease in reduction of area by about $2 \%$, compared to the value obtained for the wire rod produced following variant no. 2 , was also found. The margin of plasticity of the wire rod produced according to variant no. 3 decreased by approx. $15 \%$ compared to variant no. 2 .

Table 4 contains results for the technological properties of $5.5 \mathrm{~mm}$-diameter $20 \mathrm{MnB} 4$ steel wire rod for the examined technological variants. All results given in Tables $\mathbf{3}$ and $\mathbf{4}$ are the average values.

Table 4 The technological properties, total redundant strain angle and total true longitudinal strain of 5.5 mm-diameter 20MnB4 steel wire rod [11]

\begin{tabular}{|c|c|c|c|c|}
\hline$\sum^{\frac{\pi}{\pi}} \pm$ & $\begin{array}{c}\text { Number of twists to } \\
\text { a rupture }\end{array}$ & $\begin{array}{c}\text { Number of bends to a } \\
\text { rupture }\end{array}$ & $\begin{array}{c}\text { Total redundant strain } \\
\text { angle, } \\
\text { Y, }\end{array}$ & $\begin{array}{c}\text { Total longitudinal } \\
\text { strain, } \\
\varepsilon\end{array}$ \\
\hline 1 & 37.4 & 25.3 & 66.9 & 0.94 \\
\hline 2 & 40.4 & 28.8 & 68.5 & 1.00 \\
\hline 3 & 35.8 & 22.8 & 66.0 & 0.90 \\
\hline
\end{tabular}


A general view of $20 \mathrm{MnB} 4$ steel specimens used in technological testing is shown in Figures $\mathbf{3} \mathbf{- 5}$. The highest technological property values were exhibited by wire rod produced following variant no. 2 , where the RSM block temperature was $850^{\circ} \mathrm{C}$, while the rate of cooling in the STELMOR® line equalled $10^{\circ} \mathrm{C} / \mathrm{s}$. Thus obtained finished product had also the greatest values of the total redundant strain angle and the total true longitudinal strain. Wire rod rolled in the RSM block at $800{ }^{\circ} \mathrm{C}$ and cooled on the roller conveyor at a cooling rate of $0.5^{\circ} \mathrm{C} / \mathrm{s}$ (variant no. 3) had the lowest values of the examined parameters. To determine the ability of the wire rod to be further cold plastically worked, upsetting tests were additionally carried out in accordance with standard $\mathrm{PN}-83 / \mathrm{H}-04411$ and the evaluation of surface quality for the occurrence of any cracks was made (Figure 5). No scratches, cracks or any other surface defect types were found to occur on the upset specimen surface, even after employing a relative plastic deformation of $75 \%$.

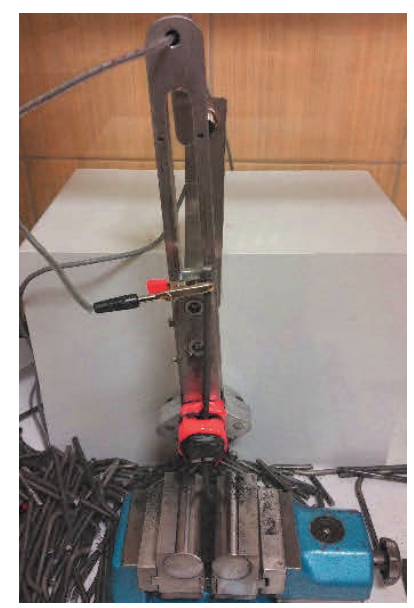

Figure $320 \mathrm{MnB} 4$ steel wire rod during bending testing

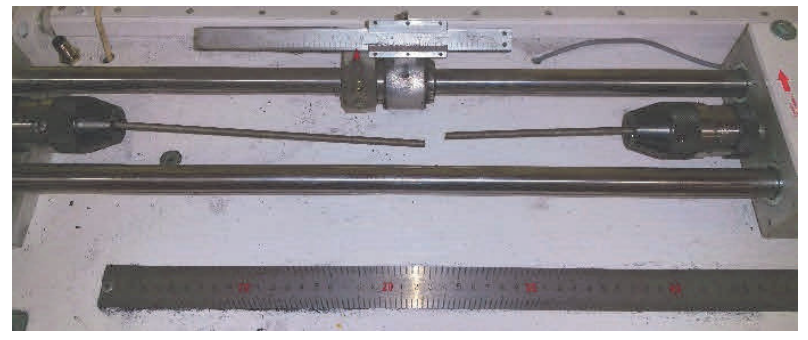

Figure 4 20MnB4 steel wire rod during torsion testing

\section{CONCLUSIONS}

Based on the analyses of the results of investigation into the effect of microstructure banding on the mechanical and technological properties of wire rod of steel $20 \mathrm{MnB} 4$, the following conclusions have been drawn:

- the intensification of the microstructure banding of the investigated steel is influenced by rolling process parameters, chiefly rolling end temperature and the rate of cooling after deformation;

- $\quad$ in the examined range of thermoplastic working parameters, conditions particularly favourable for the formation of an adverse 20MnB4 steel microstructure banding occurred when the deformation end temperature was about $800^{\circ} \mathrm{C}$ and the rate of cooling in the STELMOR® line equalled $0.5^{\circ} \mathrm{C} / \mathrm{s}$, while the least banding occurred after deforming wire rod in the RSM block at a temperature of $850{ }^{\circ} \mathrm{C}$ and cooling on the roller conveyor at a cooling rate of $10^{\circ} \mathrm{C} / \mathrm{s}$;

- $\quad$ in the examined range of thermoplastic working parameters, increasing the post-deformation cooling rate causes a decrease of banding in the steel grade under investigation;

- in the examined range of thermoplastic working parameters, the intensification of microstructure banding 
decreases the mechanical and technological properties of the steel grade under investigation;

- $\quad$ the observed microstructure banding did not affect the ability of the investigated steel grade to be subsequently cold plastic worked. As a result of employing similar thermoplastic working parameters in the rolling technology used so far, the obtained product did not always meet the standards currently in force, or met them only to a minimal extent. It has been found that, in addition to the correctly selected thermoplastic working parameters, the metallurgical purity of the rolling process feedstock is also of importance, which therefore should be free from any impurities or discontinuities.

\section{ACKNOWLEDGEMENTS}

This research work was financed from the resources of the National Research and Development

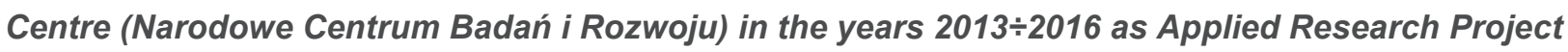
No. PBS2/A5/32/2013.

\section{REFERENCES}

[1] MARCISZ J., GARBARZ B. and ŻAK A. Przyczyny powstawania pasmowości mikrostruktury w wyrobach walcowanych na gorąco ze stali ferrytyczno-perlitycznych [Causes of the formation of microstructural banding in hot rolled products of ferritic-pearlitic steels]. Hutnik, Wiadomości Hutnicze.2007. vol. 74, no. 12, pp. 655-663.

[2] HERIAN J, and SUŁKOWSKI R. Oddziaływanie stopnia przerobu plastycznego na własności prętów walcowanych na gorąco z wlewków ciągłych [The influence of the plastic working degree on the properties of bars hot rolled from continuous castings]. Hutnik, Wiadomości Hutnicze. 2011. vol. 78, no. 8, pp. 622-624.

[3] HERIAN J. SUŁKOWSKI R. and ANIOŁEK K. Wpływ stopnia przerobu wlewka ciągłego na jednorodność własności prętów walcowanych na gorąco [The effect of the concast plastic working degree on the homogeneity of hot rolled bars] Hutnik, Wiadomości Hutnicze. 2010. vol. 76, no. 6, pp. 278-282.

[4] GROBTERLINDER R., KAWALLA R., LOTTER U.and PIRCHER H. Formation of pearlitic banded structures in ferritic-pearlitic steels. Steel Research. 1992. vol. 63, no. 8, pp. 331-336.

[5] GRANGE R.A: Effect of microstructural banding in steel. Metallurgical Transactions. 1971. vol. 2, no. 2, pp. 417426.

[6] LABER K. and KOCZURKIEWICZ B. Determination of optimum conditions for the process of controlled cooling of rolled products with diameter $16.5 \mathrm{~mm}$ made of 20MnB4 steel. In METAL 2015: 24th International Conference on Metallurgy and Materials. Ostrava: TANGER, 2015, pp. 364-370.

[7] THOMPSON S.W. and HOWELL P.R. Factors influencing ferrite/pearlite banding and origin of large pearlite nodules in a hypoeutectoid plate steel. Materials Science and Technology. 1992. vol. 8, no. 9, pp. 777-784.

[8] OFFERMAN S.E., VAN DIJK N.H., REKVELDT M.Th., SIETSMA J. and VAN DER ZWAAG S. Ferrite/pearlite band formation in hot rolled medium carbon steel. Materials Science and Technology. 2002. vol. 18, no. 3, pp. 297-303.

[9] MARCISZ J., ŻAK A.and GARBARZ B. Metody poprawy jednorodności i plastyczności półwyrobów i wyrobów ze stali odlewanej we wlewki COS i walcowanych lub kutych na gorąco z małym stopniem przerobu [Methods of improving the homogeneity and ductility of semi-finished products and products of cast into CSC castings and hot rolled or forged with a small working degree]. Prace IMŻ, 2007. vol. 59, no. 1, pp. 51-53.

[10] KUC D., SZALA J. and BEDNARCZYK I. Quantitative evaluation of the microstructure and mechanical properties of hot rolled 23MnB4 steel grade for cold upsetting. Archives of Metallurgy and Materials. 2017. vol. 62, no. 2, pp. 551-556.

[11] LABER K. Nowe aspekty wytwarzania walcówki ze stali do spęczania na zimno (monograph). 1st ed. Czestochowa: Faculty Press of the Faculty of Production Engineering and Materials Technology at the Czestochowa University of Technolog, 2018. p. 125.

[12] Suliga M. Effect of the drawing speed on the delaminations in the torsion test of high-carbon steel wires. Archives of Metallurgy and Materials. 2019. vol. 64, no. 2, pp. 671-675.

[13] KNAP F., KRUZEL R. and CIEŚLAK Ł. Ciągnienie drutów, prętów i rur [Drawing of wires and tubes]. 1st ed. Czestochowa: Faculty Press of the Faculty of Process \& Materials Engineering and Applied Physics at the Czestochowa University of Technology, 2004. P. 89. 